\title{
HIV Infection and HIV-Associated Behaviors Among Persons Who Inject Drugs - 23 Metropolitan Statistical Areas, United States, 2018
}

\author{
Senad Handanagic, $\mathrm{MD}^{1}$; Teresa Finlayson, $\mathrm{PhD}^{1}$; Janet C. Burnett, $\mathrm{MPH}^{1}$; Dita Broz, $\mathrm{PhD}^{1}$; Cyprian Wejnert, $\mathrm{PhD}^{1}$; \\ National HIV Behavioral Surveillance Study Group
}

In the United States, $10 \%$ of HIV infections diagnosed in 2018 were attributed to unsafe injection drug use or male-tomale sexual contact among persons who inject drugs (PWID) (1). In 2017, among PWID or men who have sex with men and who inject drugs (MSM-ID), 76\% of those who received a diagnosis of HIV infection lived in urban areas* (2). To monitor the prevalence of HIV infection and associated behaviors among persons who reported injecting drugs in the past 12 months, including MSM-ID, CDC's National HIV Behavioral Surveillance (NHBS) conducts interviews and HIV testing among populations of persons at high risk for HIV infection (MSM, PWID, and heterosexually active adults at increased risk for HIV infection) in selected metropolitan statistical areas (MSAs) (3). The estimated HIV infection prevalence among PWID in 23 MSAs surveyed in 2018 was 7\%. Among HIV-negative PWID, an estimated 26\% receptively shared syringes and $68 \%$ had condomless vaginal sex during the preceding 12 months. During the same period, 57\% had been tested for HIV infection, and 55\% received syringes from a syringe services program (SSP). While overall SSP use did not significantly change since 2015 , a substantial decrease in SSP use occurred among Black PWID, and HIV prevalence among Black PWID was higher than that among Hispanic and White PWID. These findings underscore the importance of continuing and expanding HIV prevention programs and community-based strategies for PWID, such as those provided by SSPs, especially following service disruptions created by the COVID-19 pandemic (4). Efforts are needed to ensure that PWID have low-barrier access to comprehensive and integrated needs-based SSPs (where legally permissible) that include provision of sterile syringes and safe syringe disposal, HIV

\footnotetext{
*Urban areas include metropolitan statistical areas with populations of $\geq 500,000$ persons; areas with populations of $<500,000$ persons were considered nonurban.
}

and hepatitis $\mathrm{C}$ virus (HCV) testing and referrals to HIV and HCV treatment, HIV preexposure prophylaxis, and treatment for substance use and mental health disorders.

In 2018, NHBS staff in $23 \mathrm{MSAs}^{\dagger}$ collected cross-sectional behavioral survey data and conducted HIV testing among

\footnotetext{
${ }^{\dagger}$ Atlanta, Georgia; Baltimore, Maryland; Boston, Massachusetts; Chicago, Illinois; Dallas, Texas; Denver, Colorado; Detroit, Michigan; Houston, Texas; Los Angeles, California; Memphis, Tennessee; Miami, Florida; Nassau-Suffolk, New York; New Orleans, Louisiana; New York, New York; Newark, New Jersey; Philadelphia, Pennsylvania; Portland, Oregon; San Diego, California; San Francisco, California; San Juan, Puerto Rico; Seattle, Washington; Virginia Beach, Virginia; Washington, District of Columbia.
}

\section{INSIDE}

1466 Self-Management Education Class Attendance and Health Care Provider Counseling for Physical Activity Among Adults with Arthritis United States, 2019

1472 Mycobacterium porcinum Skin and Soft Tissue Infections After Vaccinations — Indiana, Kentucky, and Ohio, September 2018-February 2019

1478 Temporal Trends in Dietary Sodium Intake Among Adults Aged $\geq 19$ Years — United States, 2003-2016

1483 Effectiveness of Pfizer-BioNTech mRNA Vaccination Against COVID-19 Hospitalization Among Persons Aged 12-18 Years - United States, June-September 2021

1489 Notes from the Field: A Pediatric HIV Outbreak in Ratodero, Pakistan - April 2019-April 2020

1491 QuickStats

Continuing Education examination available at https://www.cdc.gov/mmwr/mmwr_continuingEducation.html

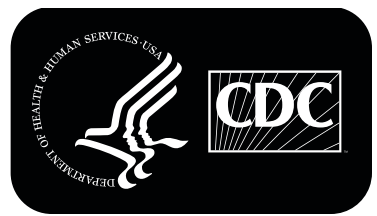

U.S. Department of Health and Human Services Centers for Disease Control and Prevention 
PWID; participants were recruited by respondent-driven sampling $\$$ (5). Eligible participants $\$$ completed a standardized behavioral questionnaire administered in person by trained interviewers. All participants were offered anonymous HIV testing.** Incentives were offered for completing the interview, receiving HIV testing, and recruiting additional participants. ${ }^{\dagger \dagger}$ Participants were asked about high-risk HIV acquisition behaviors in the previous 12 months, including receptive sharing

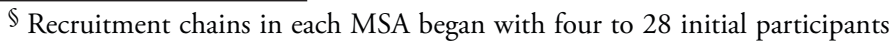
identified during formative assessment (the process by which researchers define a community of interest, determine how to access that community, and describe the attributes of the community that are relevant to a specific public health issue). Initial participants who participated in the survey were asked to recruit up to five other persons who inject drugs using a coded coupon system designed to track referrals. All eligible participants were asked to recruit up to five other persons who inject drugs. Respondent-driven sampling analysis was done using RDS Analyst version 0.7.

I Eligible participants were persons who injected drugs that were not prescribed to them by a physician during the previous 12 months, resided in the MSA, were aged $\geq 18$ years, could complete the interview in English or Spanish, and provided informed consent.

** All 23 MSAs conducted HIV screening with a rapid test; for supplemental testing to confirm rapid tests, 19 conducted a second orthogonal rapid test, one collected blood via venipuncture, and three collected blood via dried blood spots. A nonreactive rapid test result was considered HIV-negative, and a reactive rapid test result was considered HIV-positive, if supported by a second rapid test or supplemental laboratory-based testing.

$\dagger^{\dagger}$ The incentive format (cash or gift card) and amount varied by MSA based on formative assessment and local policy. A typical format included $\$ 25$ for completing the interview, $\$ 25$ for providing a specimen for HIV testing, and $\$ 10$ for each successful recruitment (maximum of five).
}

of syringes and injection equipment ${ }^{\$ \$}$ or high-risk sexual behaviors, 99 as well as testing for HIV and HCV infection, participation in HIV behavioral interventions, ${ }^{* * *}$ and receipt of syringes from SSPs ${ }^{\dagger \dagger \dagger}$ and other sources. Because knowledge of personal HIV infection status could influence risk behaviors, analysis of behavioral data was limited to HIV-negative PWID. $\$ \$ \$ S$ Nonheterosexual sexual behavior is not reported in the analysis of high-risk behaviors because the number of HIV-negative MSM-ID in the sample was too small to produce reliable weighted estimates across all 23 MSAs. Data from each MSA were analyzed by using RDS Analyst version 0.7,

\footnotetext{
$\mathbb{S}$ Receptive sharing of syringes was defined as using needles that someone else had already used to inject with, and receptive sharing of injection equipment was defined as using equipment such as cookers, cottons, or water used to rinse needles or prepare drugs that someone else had already used.

Is Condomless vaginal sex and condomless anal sex were defined as sex without a condom at least once in the past 12 months. Ascertainment of male-to-male anal sexual contact includes both insertive and receptive anal sexual contact.

*** Participating in an individual or group HIV behavioral intervention was defined as a conversation with a counselor or an organized discussion regarding prevention of HIV infection and did not include counseling received as part of an HIV test or conversations with friends.

i†† Receiving a syringe from an SSP was defined as receiving a sterile syringe or a needle at least once from a needle or syringe exchange program during the previous 12 months. Medication for opioid use disorder includes treatment with methadone, buprenorphine, and Suboxone or Subutex.

$\$ \$ \$$ Behavioral analyses from previous reports (https://doi.org/10.15585/mmwr. mm6701a5) excluded participants reporting a previous HIV-positive test result. A comparison of analysis excluding those who previously had received a positive HIV test result did not yield significantly different estimates.
}

The MMWR series of publications is published by the Center for Surveillance, Epidemiology, and Laboratory Services, Centers for Disease Control and Prevention (CDC), U.S. Department of Health and Human Services, Atlanta, GA 30329-4027.

Suggested citation: [Author names; first three, then et al., if more than six.] [Report title]. MMWR Morb Mortal Wkly Rep 2021;70:[inclusive page numbers].

\section{Centers for Disease Control and Prevention Rochelle P. Walensky, MD, MPH, Director \\ Debra Houry, MD, MPH, Acting Principal Deputy Director \\ Daniel B. Jernigan, MD, MPH, Deputy Director for Public Health Science and Surveillance \\ Rebecca Bunnell, PhD, MEd, Director, Office of Science \\ Jennifer Layden, MD, PhD, Deputy Director, Office of Science \\ Michael F. Iademarco, MD, MPH, Director, Center for Surveillance, Epidemiology, and Laboratory Services}

MMWR Editorial and Production Staff (Weekly)

\footnotetext{
Charlotte K. Kent, PhD, MPH, Editor in Chief Jacqueline Gindler, MD, Editor

Brian A. King, PhD, MPH, Guest Science Editor

Paul Z. Siegel, MD, MPH, Associate Editor

Mary Dott, MD, MPH, Online Editor

Terisa F. Rutledge, Managing Editor

Teresa M. Hood, MS, Lead Technical Writer-Editor

Leigh Berdon, Glenn Damon, Soumya Dunworth, PhD,

Srila Sen, MA, Stacy Simon, MA,

Jeffrey D. Sokolow, MA, Morgan Thompson, Technical Writer-Editors
}

Matthew L. Boulton, MD, MPH

Carolyn Brooks, ScD, MA

Jay C. Butler, MD

Virginia A. Caine, MD

Jonathan E. Fielding, MD, MPH, MBA

David W. Fleming, MD
Martha F. Boyd, Lead Visual Information Specialist Alexander J. Gottardy, Maureen A. Leahy,
Julia C. Martinroe, Stephen R. Spriggs, Tong Yang, Visual Information Specialists
Quang M. Doan, MBA, Phyllis H. King,
Terraye M. Starr, Moua Yang,
Information Technology Specialists

Ian Branam, MA,

Acting Lead Health Communication Specialist

Shelton Bartley, MPH,

Lowery Johnson, Amanda Ray,

Health Communication Specialists

Will Yang, MA,

Visual Information Specialist

\section{MMWR Editorial Board}

Timothy F. Jones, MD, Chairman

William E. Halperin, MD, DrPH, MPH

Jewel Mullen, MD, MPH, MPA

Jeff Niederdeppe, $\mathrm{PhD}$

Celeste Philip, MD, MPH

Patricia Quinlisk, MD, MPH

Patrick L. Remington, MD, MPH
Carlos Roig, MS, MA William Schaffner, MD

Nathaniel Smith, MD, MPH

Morgan Bobb Swanson, BS

Abbigail Tumpey, MPH 
producing estimates adjusted for peer-recruitment patterns and reported network size along with estimated $95 \%$ confidence intervals (CIs) (5). To calculate aggregated prevalence of HIV and selected behaviors that are generalizable to PWID across the 23 MSAs, NHBS used a weighted average of MSA-level estimates adjusted for the projected size of the population of PWID in each MSA (6).999 Comparisons were considered significant if there was no overlap in their 95\% CIs. This activity was reviewed by CDC and was conducted consistent with applicable federal law and CDC policy.****

In $2018,14,716$ persons were recruited to participate in NHBS; 3,138 (21\%) were ineligible, and 230 (2\%) were excluded because data were incomplete. ${ }^{\dagger \dagger \dagger}$ Among the 11,348 PWID who were tested for HIV, 731 (6\%) received positive test results and 10,617 (94\%) received negative results (Table 1). Weighted HIV prevalence in the 23 MSAs was $7 \%$, with the highest prevalences among MSM-ID (25\%), PWID aged 40-49 years (12\%), and Black or African American (Black) PWID (12\%). HIV prevalence among Black PWID was higher than that among Hispanic (7\%) and White (5\%) PWID.

Among HIV-negative PWID, 26\% receptively shared syringes, $68 \%$ had condomless vaginal sex, $23 \%$ had condomless heterosexual anal sex, $72 \%$ had either condomless heterosexual sex or shared syringes, and $43 \%$ had more than one opposite sex partner (Table 2). Receptive syringe sharing was higher among White (36\%) than among Hispanic (22\%) or Black (16\%) PWID. Condomless vaginal sex was higher among White $(73 \%)$ than among Hispanic (63\%) or Black (63\%) PWID, and condomless heterosexual anal sex was higher among Hispanic (30\%) and White (24\%) than among Black PWID (16\%).

In the previous 12 months, among HIV-negative PWID, $57 \%$ received an HIV test, $33 \%$ participated in an HIV behavioral intervention, 55\% received syringes from SSPs, and 56\% used medication for opioid use disorder (Table 3). Among PWID who were HIV-negative, 83\% reported having had a test for HCV in their lifetime and $46 \%$ reported being HCV-positive. Fewer White PWID were tested for HIV in the preceding 12 months (53\%) than were Hispanic (62\%) PWID. Fewer Black PWID received syringes from SSPs (40\%) than did Hispanic (63\%) or White PWID (63\%) or used medication for

\footnotetext{
999 For MSA-level estimates for which CIs could not be calculated, maximally wide CIs (0-1) were used in aggregation. MSA-level estimates with insufficient data for analysis were excluded from the aggregated estimates. Aggregated estimates are included in the tables only if $\geq 15$ out of 23 MSAlevel estimates were included in the analysis. The highest number of missing MSA-level estimates for one variable was five.

**** 45 C.F.R. part 46.102(l)(2), 21 C.F.R. part 56; 42 U.S.C. Sect. 241(d); 5 U.S.C. Sect. 552a; 44 U.S.C. Sect. 3501 et seq.

titt Data from 230 participants were excluded because of missing recruitment data, lost data during electronic upload, incomplete survey data, and survey responses with questionable validity or invalid HIV test results. Reasons for exclusion were not mutually exclusive.
}

opioid use disorder ( $47 \%$ versus $65 \%$ and $58 \%$, respectively). More PWID with health insurance were tested for HIV infection in the previous 12 months (59\%), participated in HIV behavioral interventions (35\%), ever tested for HCV infection $(86 \%)$, and received medication for opioid use disorder (61\%) than did PWID without health insurance (47\%, 22\%, 71\%, and $35 \%$, respectively) (Table 3 ).

\section{Discussion}

This report provides updated weighted prevalence estimates of HIV infection and behaviors associated with HIV infection since the last NHBS survey among PWID in 2015 (3) and represents a snapshot of the HIV prevention landscape for U.S. PWID before the COVID-19 pandemic. In 2018, PWID reported injection and sexual behaviors that placed them at increased risk for HIV infection, highlighting the need for effective and comprehensive prevention services, including access to sterile injection equipment.

From 2015 to 2018, HIV prevalence among PWID in selected MSAs was unchanged at 7\%. This analysis found a higher HIV prevalence among Black PWID than among Hispanic or White PWID, despite fewer reported risk behaviors associated with HIV infection among Black PWID. In 2018, when compared with Hispanic or White PWID, fewer Black PWID shared syringes or injection equipment and had condomless anal sex. Overall, SSP use did not significantly increase since 2015 (from 52\% to 55\%), but a substantial decrease in SSP use among Black PWID (from 51\% to $40 \%$ ), and significantly lower use of SSPs in 2018 among Black PWID compared with Hispanic and White PWID was observed. Lower SSP use among Black PWID in the context of disproportionally higher rates of HIV diagnoses in Black communities (1) might lead to increased risk for HIV transmission among Black PWID. It is critical to explore and address the causes for these disparities in SSP use and HIV infection rates.

In 2020, the COVID-19 pandemic impeded delivery of prevention services for PWID nationally, resulting in a substantial reduction in SSP operations and provision of medication for opioid use disorder (4). This analysis highlights the ongoing need for risk reduction and improved access to HIV prevention services among PWID than existed before the COVID-19 pandemic, especially because access to these services was reduced as a result of the pandemic. Findings from this analysis and continuous monitoring of characteristics and risk behaviors associated with HIV infection of PWID will facilitate estimation of how the pandemic disrupted behaviors as well as access to essential prevention services among PWID.

The findings in this report are subject to at least four limitations. First, because a method of obtaining standard probability-based samples of PWID does not exist, the 
TABLE 1. HIV prevalence among persons who inject drugs, by selected characteristics — National HIV Behavioral Surveillance, 23 Metropolitan Statistical Areas, United States, 2018

\begin{tabular}{|c|c|c|c|c|}
\hline \multirow[b]{2}{*}{ Characteristic } & \multicolumn{2}{|c|}{ Total* } & \multicolumn{2}{|c|}{ HIV-infected* } \\
\hline & $\mathrm{No}^{\dagger}$ & Column \% $(95 \% \mathrm{Cl})$ & No. $^{\dagger}$ & Row \% $(95 \% \mathrm{Cl})$ \\
\hline Total & 11,348 & 100 & 731 & $7(6-9)$ \\
\hline $\begin{array}{l}\text { Gender } \\
\text { Male } \\
\text { Female } \\
\text { Transgender }\end{array}$ & $\begin{array}{r}7,826 \\
3,425 \\
97\end{array}$ & $\begin{array}{r}67(65-69) \\
32(30-34) \\
1.0(0.7-1.3)\end{array}$ & $\begin{array}{r}500 \\
204 \\
27\end{array}$ & $\begin{array}{r}7(6-8) \\
8(5-11) \\
-\S\end{array}$ \\
\hline $\begin{array}{l}\text { Race/Ethnicity } \\
\text { Black, non-Hispanic } \\
\text { Hispanic } \\
\text { White, non-Hispanic } \\
\text { Other** }\end{array}$ & $\begin{array}{r}3,745 \\
2,358 \\
4,458 \\
189\end{array}$ & $\begin{array}{r}32(30-34) \\
24(22-26) \\
42(40-43) \\
2(1-2)\end{array}$ & $\begin{array}{r}335 \\
188 \\
171 \\
12\end{array}$ & $\begin{array}{r}12(9-14) \\
7(5-8) \\
5(4-6) \\
-\end{array}$ \\
\hline $\begin{array}{l}\text { Age group, yrs } \\
18-29 \\
30-39 \\
40-49 \\
\geq 50\end{array}$ & $\begin{array}{l}1,618 \\
2,999 \\
2,631 \\
4,100\end{array}$ & $\begin{array}{l}15(14-17) \\
23(21-25) \\
24(22-25) \\
38(36-40)\end{array}$ & $\begin{array}{r}63 \\
138 \\
201 \\
329\end{array}$ & $\begin{array}{r}4(3-6) \\
5(4-6) \\
12(8-15) \\
8(6-10)\end{array}$ \\
\hline $\begin{array}{l}\text { Injection duration } \\
\leq 5 \text { years } \\
>5 \text { years }\end{array}$ & $\begin{array}{l}2,073 \\
9,207\end{array}$ & $\begin{array}{l}20(18-21) \\
80(79-82)\end{array}$ & $\begin{array}{r}77 \\
647\end{array}$ & $\begin{array}{r}5(3-7) \\
8(7-10)\end{array}$ \\
\hline $\begin{array}{l}\text { Education } \\
\text { Less than high school diploma } \\
\text { High school diploma } \\
\text { More than high school diploma }\end{array}$ & $\begin{array}{l}3,240 \\
4,689 \\
3,416\end{array}$ & $\begin{array}{l}29(27-30) \\
42(40-44) \\
30(28-31)\end{array}$ & $\begin{array}{l}240 \\
310 \\
181\end{array}$ & $\begin{array}{r}8(6-10) \\
9(6-11) \\
6(5-8)\end{array}$ \\
\hline $\begin{array}{l}\text { Currently insured } \\
\text { No } \\
\text { Yes }\end{array}$ & $\begin{array}{l}2,940 \\
8,362\end{array}$ & $\begin{array}{l}18(16-19) \\
82(81-84)\end{array}$ & $\begin{array}{l}151 \\
580\end{array}$ & $\begin{array}{r}5(4-7) \\
8(6-10)\end{array}$ \\
\hline $\begin{array}{l}\text { Federal poverty level }{ }^{\dagger \dagger} \\
\text { Above federal poverty level } \\
\text { At or below federal poverty level }\end{array}$ & $\begin{array}{l}2,771 \\
8,505\end{array}$ & $\begin{array}{l}25(23-27) \\
75(73-77)\end{array}$ & $\begin{array}{l}134 \\
596\end{array}$ & $\begin{array}{l}7(5-9) \\
8(6-9)\end{array}$ \\
\hline $\begin{array}{l}\text { Drug injected most frequently } \\
\text { Heroin only } \\
\text { Other/Multiple } \\
\S \S\end{array}$ & $\begin{array}{l}6,031 \\
5,273\end{array}$ & $\begin{array}{l}55(53-56) \\
45(44-47)\end{array}$ & $\begin{array}{l}282 \\
444\end{array}$ & $\begin{array}{r}6(4-7) \\
10(8-12)\end{array}$ \\
\hline $\begin{array}{l}\text { Male-to-male sex, last } 12 \text { month } \\
\text { Yes } \\
\text { No }\end{array}$ & $\begin{array}{r}753 \\
7,067\end{array}$ & $\begin{array}{r}10(8-12) \\
90(88-92)\end{array}$ & $\begin{array}{l}151 \\
349\end{array}$ & $\begin{array}{r}25(19-30) \\
5(4-6)\end{array}$ \\
\hline $\begin{array}{l}\text { U.S. Census region }{ }^{* * *} \\
\text { Northeast } \\
\text { South } \\
\text { Midwest } \\
\text { West }\end{array}$ & $\begin{array}{l}2,257 \\
4,650 \\
1,062 \\
2,888\end{array}$ & $\begin{array}{r}36(22-49) \\
29(16-42) \\
8(0-21) \\
26(12-39)\end{array}$ & $\begin{array}{r}180 \\
365 \\
17 \\
112\end{array}$ & $\begin{array}{r}10(7-14) \\
9(7-11) \\
1(0-2) \\
4(3-5)\end{array}$ \\
\hline
\end{tabular}

Abbreviations: $\mathrm{Cl}$ = confidence interval; $\mathrm{MSA}=$ metropolitan statistical area.

* Aggregate estimates are weighted averages of MSA-level percentages. MSA-level percentages were adjusted for differences in recruitment and the size of participant peer networks of persons who inject drugs, then proportionally weighted by the size of the population of persons who inject drugs in each MSA. MSA-level estimates with insufficient data for analysis were excluded from the aggregated estimates. Aggregated estimates are included in the tables only if at least 15 out of 23 MSA-level estimates were included in the analysis. The average number of MSA-level estimates included in the aggregated estimates for each variable is 21.3 .

† Unweighted numbers. Not all categories sum to 11,348 because of missing data.

$\S$ Insufficient data to calculate estimates.

१ Hispanic persons might be of any race or combination of races.

** Includes American Indian or Alaska Native, Asian, Native Hawaiian or Other Pacific Islander, and persons of multiple races.

${ }^{+t}$ Poverty level is based on household income and household size.

$\S \S$ Other drugs injected alone or two or more drugs injected with the same frequency.

१ศ Ascertainment of male-to-male anal sexual contact was restricted to males and includes both insertive and receptive anal sexual contact.

*** Northeast: Boston, Massachusetts; Nassau-Suffolk, New York; New York City, New York; Newark, New Jersey; and Philadelphia, Pennsylvania. South: Atlanta, Georgia; Baltimore, Maryland; Dallas, Texas; Houston, Texas; Memphis, Tennessee; Miami, Florida; New Orleans, Louisiana; Virginia Beach, Virginia; and Washington, District of Columbia. Midwest: Chicago, Illinois and Detroit, Michigan. West:Denver, Colorado; Los Angeles, California; Portland, Oregon; San Diego, California; San Francisco, California; and Seattle, Washington. San Juan, Puerto Rico was not included in any of the Census regions.

representativeness of the NHBS sample cannot be determined. Although adjustments were made to the sampling methodology (5), biases related to participants' recruitment behavior or their willingness and ability to participate in the interview might have affected the sample. Second, insufficient numbers of participants in some cities precluded inclusion of these cities in the aggregate estimates. The number of MSAs excluded from aggregate estimates varied based on the analysis 
TABLE 2. Estimated percentage* of persons who inject drugs who received negative HIV test results and engaged in behaviors ${ }^{\dagger}$ associated with HIV infection in the preceding 12 months, by selected characteristics - National HIV Behavioral Surveillance, 23 Metropolitan Statistical Areas, United States, 2018

\begin{tabular}{|c|c|c|c|c|c|c|c|c|}
\hline \multirow[b]{2}{*}{ Characteristic } & \multicolumn{8}{|c|}{$\%(95 \% \mathrm{Cl})$} \\
\hline & $\begin{array}{l}\text { Receptive } \\
\text { syringe } \\
\text { sharing }^{\dagger}\end{array}$ & $\begin{array}{l}\text { Receptive } \\
\text { injection } \\
\text { equipment } \\
\text { sharing }^{\dagger}\end{array}$ & $\begin{array}{l}\text { Vaginal } \\
\text { sex }\end{array}$ & $\begin{array}{l}\text { Condomless } \\
\text { vaginal sex }\end{array}$ & $\begin{array}{l}\text { Heterosexual } \\
\text { anal sex }\end{array}$ & $\begin{array}{l}\text { Condomless } \\
\text { heterosexual } \\
\text { anal sex }\end{array}$ & $\begin{array}{l}\text { Condomless } \\
\text { heterosexual } \\
\text { sex }{ }^{\dagger} \text { or receptive } \\
\text { syringe sharing }\end{array}$ & $\begin{array}{l}\text { More than } \\
\text { one opposite } \\
\text { sex partner }\end{array}$ \\
\hline Total & $26(25-28)$ & $49(47-51)$ & 77 (75-79) & $68(66-70)$ & $29(27-31)$ & $23(22-25)$ & $72(70-74)$ & $43(41-46)$ \\
\hline $\begin{array}{l}\text { Sex } \\
\text { Male } \\
\text { Female }\end{array}$ & $\begin{array}{l}24(22-26) \\
31(28-34)\end{array}$ & $\begin{array}{l}48(46-50) \\
50(47-54)\end{array}$ & $\begin{array}{l}75(72-77) \\
81(78-84)\end{array}$ & $\begin{array}{l}64(61-66) \\
76(73-79)\end{array}$ & $\begin{array}{l}28(26-30) \\
32(28-35)\end{array}$ & $\begin{array}{l}21(20-23) \\
27(24-31)\end{array}$ & $\begin{array}{l}69(67-72) \\
78(75-81)\end{array}$ & $\begin{array}{l}41(39-44) \\
48(44-51)\end{array}$ \\
\hline $\begin{array}{l}\text { Race/Ethnicity } \\
\text { Black, non-Hispanic } \\
\text { Hispanic } \\
\text { White, non-Hispanic }\end{array}$ & $\begin{array}{l}16(14-18) \\
22(19-25) \\
36(34-39)\end{array}$ & $\begin{array}{l}38(35-41) \\
46(41-51) \\
59(56-62)\end{array}$ & $\begin{array}{l}75(72-78) \\
73(68-77) \\
80(78-83)\end{array}$ & $\begin{array}{l}63(60-66) \\
63(58-68) \\
73(70-75)\end{array}$ & $\begin{array}{l}23(20-25) \\
37(33-42) \\
29(26-32)\end{array}$ & $\begin{array}{l}16(14-18) \\
30(26-33) \\
24(22-27)\end{array}$ & $\begin{array}{l}66(63-69) \\
67(62-72) \\
78(76-81)\end{array}$ & $\begin{array}{l}43(40-46) \\
41(36-45) \\
45(42-49)\end{array}$ \\
\hline $\begin{array}{l}\text { Age group, yrs } \\
18-29 \\
30-39 \\
40-49 \\
\geq 50\end{array}$ & $\begin{array}{l}41(36-46) \\
33(29-36) \\
23(20-26) \\
18(16-20)\end{array}$ & $\begin{array}{l}60(55-65) \\
54(50-57) \\
49(45-54) \\
41(38-44)\end{array}$ & $\begin{array}{l}89(86-92) \\
86(84-89) \\
77(73-81) \\
66(63-70)\end{array}$ & $\begin{array}{l}84(81-88) \\
78(75-81) \\
68(64-72) \\
55(52-58)\end{array}$ & $\begin{array}{l}36(31-41) \\
34(31-37) \\
32(28-36) \\
22(20-25)\end{array}$ & $\begin{array}{l}30(26-35) \\
29(26-32) \\
25(22-29) \\
16(14-18)\end{array}$ & $\begin{array}{l}87(84-90) \\
83(80-86) \\
72(68-76) \\
60(57-63)\end{array}$ & $\begin{array}{l}59(53-64) \\
50(47-54) \\
43(39-47) \\
35(32-37)\end{array}$ \\
\hline $\begin{array}{l}\text { Education } \\
\text { Less than high school diploma } \\
\text { High school diploma } \\
\text { More than high school diploma }\end{array}$ & $\begin{array}{l}25(22-28) \\
27(25-30) \\
27(24-29)\end{array}$ & $\begin{array}{l}48(44-51) \\
49(46-52) \\
50(46-53)\end{array}$ & $\begin{array}{l}74(70-77) \\
76(73-79) \\
81(78-84)\end{array}$ & $\begin{array}{l}64(60-68) \\
67(63-70) \\
72(69-75)\end{array}$ & $\begin{array}{l}30(27-34) \\
28(25-31) \\
30(27-33)\end{array}$ & $\begin{array}{l}23(20-26) \\
23(20-25) \\
24(21-27)\end{array}$ & $\begin{array}{l}70(66-73) \\
71(68-74) \\
75(71-78)\end{array}$ & $\begin{array}{l}40(37-44) \\
44(41-47) \\
46(43-50)\end{array}$ \\
\hline $\begin{array}{l}\text { Currently insured } \\
\text { No } \\
\text { Yes }\end{array}$ & $\begin{array}{l}32(29-35) \\
25(23-27)\end{array}$ & $\begin{array}{l}49(46-53) \\
49(46-51)\end{array}$ & $\begin{array}{l}79(76-83) \\
76(74-78)\end{array}$ & $\begin{array}{l}72(68-75) \\
67(64-69)\end{array}$ & $\begin{array}{l}30(27-33) \\
29(27-31)\end{array}$ & $\begin{array}{l}26(22-29) \\
23(21-24)\end{array}$ & $\begin{array}{l}76(73-80) \\
71(69-73)\end{array}$ & $\begin{array}{l}50(46-54) \\
42(40-45)\end{array}$ \\
\hline $\begin{array}{l}\text { Federal poverty level } \\
\text { Above federal poverty level } \\
\text { At or below federal poverty level }\end{array}$ & $\begin{array}{l}26(23-29) \\
26(25-28)\end{array}$ & $\begin{array}{l}49(45-53) \\
49(47-51)\end{array}$ & $\begin{array}{l}83(80-86) \\
75(73-77)\end{array}$ & $\begin{array}{l}74(70-78) \\
66(63-68)\end{array}$ & $\begin{array}{l}28(24-32) \\
30(28-32)\end{array}$ & $\begin{array}{l}22(19-25) \\
24(22-26)\end{array}$ & $\begin{array}{l}77(74-81) \\
70(68-73)\end{array}$ & $\begin{array}{l}45(41-49) \\
43(41-45)\end{array}$ \\
\hline $\begin{array}{l}\text { Drug injected most frequently } \\
\text { Heroin only } \\
\text { Other/Multiple } \\
\text { Ot† }^{-}\end{array}$ & $\begin{array}{l}26(24-28) \\
27(25-29)\end{array}$ & $\begin{array}{l}49(47-51) \\
50(47-53)\end{array}$ & $\begin{array}{l}75(72-77) \\
79(77-82)\end{array}$ & $\begin{array}{l}66(63-68) \\
70(67-73)\end{array}$ & $\begin{array}{l}25(23-27) \\
34(32-37)\end{array}$ & $\begin{array}{l}19(17-21) \\
28(25-31)\end{array}$ & $\begin{array}{l}70(67-73) \\
74(72-77)\end{array}$ & $\begin{array}{l}38(36-41) \\
50(47-53)\end{array}$ \\
\hline $\begin{array}{l}\text { U.S. Census region } \$ \S \\
\text { Northeast } \\
\text { South } \\
\text { Midwest } \\
\text { West }\end{array}$ & $\begin{array}{l}27(24-30) \\
28(25-30) \\
21(17-25) \\
25(22-28)\end{array}$ & $\begin{array}{l}50(46-54) \\
50(47-54) \\
36(32-41) \\
49(45-53)\end{array}$ & $\begin{array}{l}78(75-82) \\
78(76-81) \\
74(69-78) \\
74(70-78)\end{array}$ & $\begin{array}{l}70(66-74) \\
69(66-72) \\
60(56-65) \\
65(61-69)\end{array}$ & $\begin{array}{l}37(33-41) \\
25(22-28) \\
19(15-22) \\
26(23-29)\end{array}$ & $\begin{array}{l}29(26-33) \\
19(17-21) \\
14(11-17) \\
21(18-24)\end{array}$ & $\begin{array}{l}73(69-77) \\
75(72-78) \\
64(59-69) \\
69(65-74)\end{array}$ & $\begin{array}{l}45(41-50) \\
43(40-47) \\
35(30-39) \\
44(40-48)\end{array}$ \\
\hline
\end{tabular}

Abbreviations: $\mathrm{Cl}$ = confidence interval; $\mathrm{MSA}=$ metropolitan statistical area.

${ }^{*}$ Aggregate estimates are weighted averages of MSA level percentages. MSA-level percentages were adjusted for differences in recruitment and the size of participant peer networks of persons who inject drugs, then proportionally weighted by the size of the population of persons who inject drugs in each MSA. The average number of MSA-level estimates included in the aggregated estimates for each variable is 22.8 .

† Receptive syringe sharing was defined as using needles that someone else had already used to inject with, and receptive injection equipment sharing was defined as using equipment such as cookers, cottons, or water used to rinse needles or prepare drugs that someone else had already used. Condomless vaginal or anal sex was defined as sex without a condom.

$\S$ Aggregate estimates for "Other" race and ethnicity (American Indian or Alaska Native, Asian, Native Hawaiian or Other Pacific Islander, and person of multiple races) are excluded because of insufficient data.

" Hispanic persons might be of any race or combination of races.

** Poverty level is based on household income and household size.

${ }^{t+}$ Other drugs injected alone or two or more drugs injected with the same frequency.

$\S \S$ Northeast: Boston, Massachusetts; Nassau-Suffolk, New York; New York City, New York; Newark, New Jersey; and Philadel phia, Pennsylvania. South: Atlanta, Georgia; Baltimore, Maryland; Dallas, Texas; Houston, Texas; Memphis, Tennessee; Miami, Florida; New Orleans, Louisiana; Virginia Beach, Virginia; and Washington, District of Columbia. Midwest: Chicago, Illinois and Detroit, Michigan. West: Denver, Colorado; Los Angeles, California; Portland, Oregon; San Diego, California; San Francisco, California; and Seattle, Washington. San Juan, Puerto Rico was not included in any of the Census regions.

variable. Third, PWID were interviewed in 23 MSAs with high prevalences of HIV infection; findings from these MSAs might not be generalizable to all PWID, including residents of rural or nonmetropolitan areas. Finally, behavioral data are self-reported and subject to recall and social desirability biases.
Despite decades of evidence regarding the importance of SSPs and regular HIV testing for the prevention of HIV transmission among PWID $(7,8)$, only approximately one half of PWID used SSPs or were tested for HIV in the 12 months preceding the survey. Since 2015, the number of SSPs and the number of syringes distributed in the United States increased (9); however, 
TABLE 3. Estimated percentage* of persons who inject drugs who received negative HIV test results and participation in testing or prevention services, by selected characteristics - National HIV Behavioral Surveillance, 23 Metropolitan Statistical Areas, United States, 2018

Participation, \% $(95 \% \mathrm{Cl})$

\begin{tabular}{|c|c|c|c|c|c|c|c|}
\hline Characteristic & $\begin{array}{l}\text { Tested for HIV } \\
\text { infection } \\
\text { in past } \\
12 \text { months }\end{array}$ & $\begin{array}{l}\text { Participated in HIV } \\
\text { behavioral } \\
\text { intervention in past } \\
12 \text { months } \\
\end{array}$ & $\begin{array}{l}\text { Ever } \\
\text { tested for } \\
\text { hepatitis C }\end{array}$ & $\begin{array}{l}\text { Self-reported } \\
\text { positive for } \\
\text { hepatitis C }\end{array}$ & $\begin{array}{l}\text { Received sterile } \\
\text { syringes from } \\
\text { SSP in past } 12 \\
\text { months }{ }^{\S}\end{array}$ & $\begin{array}{l}\text { Received sterile } \\
\text { syringes from } \\
\text { pharmacy in past } \\
12 \text { months }^{\S}\end{array}$ & $\begin{array}{l}\text { Used medication to } \\
\text { treat opioid use } \\
\text { disorder in past } \\
12 \text { months }\end{array}$ \\
\hline Total & $57(55-59)$ & $33(31-35)$ & $83(82-85)$ & $46(44-49)$ & $55(53-57)$ & $36(34-38)$ & $56(54-58)$ \\
\hline $\begin{array}{l}\text { Gender } \\
\text { Male } \\
\text { Female }\end{array}$ & $\begin{array}{l}56(54-58) \\
59(56-62)\end{array}$ & $\begin{array}{l}32(30-35) \\
33(29-36)\end{array}$ & $\begin{array}{l}82(80-84) \\
86(84-88)\end{array}$ & $\begin{array}{l}47(44-49) \\
46(43-50)\end{array}$ & $\begin{array}{l}53(50-55) \\
61(58-64)\end{array}$ & $\begin{array}{l}35(32-37) \\
38(34-41)\end{array}$ & $\begin{array}{l}56(53-58) \\
58(54-61)\end{array}$ \\
\hline $\begin{array}{l}\text { Race/Ethnicity** } \\
\text { Black, non-Hispanic } \\
\text { Hispanic }{ }^{\dagger \dagger} \\
\text { White, non-Hispanic }\end{array}$ & $\begin{array}{l}59(55-62) \\
62(58-66) \\
53(50-56)\end{array}$ & $\begin{array}{l}34(31-37) \\
37(33-42) \\
29(27-32)\end{array}$ & $\begin{array}{l}80(78-82) \\
85(82-87) \\
86(84-89)\end{array}$ & $\begin{array}{l}39(36-42) \\
51(47-55) \\
51(48-54)\end{array}$ & $\begin{array}{l}40(37-42) \\
63(58-68) \\
63(60-65)\end{array}$ & $\begin{array}{l}20(17-23) \\
33(29-38) \\
46(43-49)\end{array}$ & $\begin{array}{l}47(44-50) \\
65(61-69) \\
58(55-61)\end{array}$ \\
\hline $\begin{array}{l}\text { Age group, yrs } \\
18-29 \\
30-39 \\
40-49 \\
\geq 50\end{array}$ & $\begin{array}{l}59(54-65) \\
60(56-63) \\
60(57-64) \\
52(49-55)\end{array}$ & $\begin{array}{l}28(23-33) \\
31(28-34) \\
39(34-43) \\
31(28-34)\end{array}$ & $\begin{array}{l}74(69-79) \\
86(85-88) \\
86(83-88) \\
84(82-87)\end{array}$ & $\begin{array}{l}29(24-34) \\
43(40-46) \\
49(45-54) \\
54(50-57)\end{array}$ & $\begin{array}{l}60(56-65) \\
61(58-65) \\
63(58-67) \\
46(43-49)\end{array}$ & $\begin{array}{l}52(47-56) \\
43(39-46) \\
35(31-39) \\
25(22-27)\end{array}$ & $\begin{array}{l}52(47-57) \\
61(57-64) \\
60(56-64) \\
52(49-55)\end{array}$ \\
\hline $\begin{array}{l}\text { Education } \\
\text { Less than high school diploma } \\
\text { High school diploma } \\
\text { More than high school diploma }\end{array}$ & $\begin{array}{l}59(55-62) \\
57(54-60) \\
55(52-59)\end{array}$ & $\begin{array}{l}33(29-37) \\
31(28-34) \\
34(31-37)\end{array}$ & $\begin{array}{l}84(81-86) \\
82(79-84) \\
86(84-88)\end{array}$ & $\begin{array}{l}51(47-55) \\
45(41-48) \\
45(41-48)\end{array}$ & $\begin{array}{l}54(50-58) \\
55(52-57) \\
56(52-59)\end{array}$ & $\begin{array}{l}27(24-30) \\
37(34-40) \\
42(38-45)\end{array}$ & $\begin{array}{l}59(55-62) \\
54(51-57) \\
56(53-59)\end{array}$ \\
\hline $\begin{array}{l}\text { Health insurance } \\
\text { No } \\
\text { Yes }\end{array}$ & $\begin{array}{l}47(43-51) \\
59(57-61)\end{array}$ & $\begin{array}{l}22(19-25) \\
35(33-37)\end{array}$ & $\begin{array}{l}71(68-75) \\
86(84-88)\end{array}$ & $\begin{array}{l}30(26-33) \\
50(48-53)\end{array}$ & $\begin{array}{l}40(37-43) \\
58(56-60)\end{array}$ & $\begin{array}{l}36(32-40) \\
36(33-38)\end{array}$ & $\begin{array}{l}35(31-38) \\
61(59-64)\end{array}$ \\
\hline $\begin{array}{l}\text { Federal poverty level } \$ \S \\
\text { Above federal poverty level } \\
\text { At or below federal poverty level }\end{array}$ & $\begin{array}{l}52(48-56) \\
58(56-61)\end{array}$ & $\begin{array}{l}30(27-34) \\
34(31-36)\end{array}$ & $\begin{array}{l}82(79-86) \\
84(82-85)\end{array}$ & $\begin{array}{l}43(39-47) \\
48(45-50)\end{array}$ & $\begin{array}{l}53(49-56) \\
55(53-57)\end{array}$ & $\begin{array}{l}48(43-52) \\
32(30-34)\end{array}$ & $\begin{array}{l}53(49-57) \\
57(55-59)\end{array}$ \\
\hline $\begin{array}{l}\text { Drug injected most frequently } \\
\text { Heroin only } \\
\text { Other/Multiple }\end{array}$ & $\begin{array}{l}55(52-57) \\
61(58-63)\end{array}$ & $\begin{array}{l}31(29-34) \\
34(31-37)\end{array}$ & $\begin{array}{l}85(83-86) \\
82(80-85)\end{array}$ & $\begin{array}{l}47(44-50) \\
47(44-50)\end{array}$ & $\begin{array}{l}57(55-59) \\
52(49-55)\end{array}$ & $\begin{array}{l}37(35-40) \\
33(31-36)\end{array}$ & $\begin{array}{l}62(59-64) \\
51(48-53)\end{array}$ \\
\hline $\begin{array}{l}\text { U.S. Census region }{ }^{* * *} \\
\text { Northeast } \\
\text { South } \\
\text { Midwest } \\
\text { West }\end{array}$ & $\begin{array}{l}65(62-69) \\
57(54-61) \\
50(46-55) \\
48(44-51)\end{array}$ & $\begin{array}{l}43(39-47) \\
29(26-32) \\
28(24-32) \\
23(20-26)\end{array}$ & $\begin{array}{l}88(85-91) \\
80(77-82) \\
81(77-85) \\
84(80-87)\end{array}$ & $\begin{array}{l}57(53-62) \\
39(36-42) \\
36(31-41) \\
44(40-48)\end{array}$ & $\begin{array}{l}64(60-68) \\
37(34-39) \\
43(38-48) \\
67(63-71)\end{array}$ & $\begin{array}{l}37(33-41) \\
28(25-31) \\
38(33-42) \\
42(38-46)\end{array}$ & $\begin{array}{l}69(65-73) \\
46(43-49) \\
58(53-62) \\
51(47-55)\end{array}$ \\
\hline
\end{tabular}

Abbreviations: $\mathrm{Cl}=$ confidence interval; $\mathrm{MSA}=$ metropolitan statistical area; $\mathrm{SSP}=$ syringe services program.

* Aggregate estimates are weighted averages of MSA-level percentages. MSA-level percentages were adjusted for differences in recruitment and the size of participant peer networks of persons who inject drugs, then proportionally weighted by the size of the population of persons who inject drugs in each MSA. The average number of MSA-level estimates included in the aggregated estimates for each variable is 22.9.

$\dagger$ Participating in an individual or group HIV behavioral intervention (e.g., a one-on-one conversation with a counselor or an organized discussion regarding HIV prevention) did not include counseling received as part of an HIV test or conversations with friends.

$\S$ Receiving a syringe from an SSP was defined as reporting receiving a sterile syringe or needles at least once from an SSP or syringe/needle exchange program. Receiving a syringe from a pharmacy was defined as reporting receiving a sterile syringe or needles at least once from a pharmacy.

I Includes treatment with methadone, buprenorphine, Suboxone or Subutex in the past 12 months.

** Aggregate estimates for "Other" race and ethnicity (American Indian or Alaska Native, Asian, Native Hawaiian or Other Pacific Islander, and person of multiple races) are excluded because of insufficient data.

t+ Hispanic persons might be of any race or combination of races.

$\S \S$ Poverty level is based on household income and household size.

१ी Other drugs injected alone or two or more drugs injected with the same frequency.

*** Northeast: Boston, Massachusetts; Nassau-Suffolk, New York; New York City, New York; Newark, New Jersey; and Philadelphia, Pennsylvania. South: Atlanta, Georgia; Baltimore, Maryland; Dallas, Texas; Houston, Texas; Memphis, Tennessee; Miami, Florida; New Orleans, Louisiana; Virginia Beach, Virginia; and Washington, District of Columbia. Midwest: Chicago, Illinois and Detroit, Michigan. West: Denver, Colorado; Los Angeles, California; Portland, Oregon; San Diego, California; San Francisco, California; and Seattle, Washington. San Juan, Puerto Rico was not included in any of the Census regions.

this analysis found no significant increase in the overall use of SSPs and a substantial reduction in SSP use among Black PWID compared with 2015. The ongoing drug-use epidemic has increased the potential for HIV outbreaks among PWID, particularly in areas and among groups that have limited access to prevention services such as SSPs and medications for opioid use disorder (10).
For progress to be made toward achieving the goals of the federal

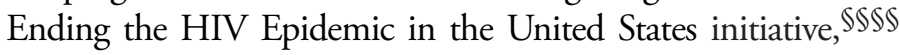
PWID need to have low-barrier access to comprehensive and integrated needs-based SSPs (where legally permissible) that

\footnotetext{
$\overline{\$ S \$ S ~ h t t p s: / / w w w . h r s a . g o v / e n d i n g-h i v-e p i d e m i c ~}$
} 


\section{Summary}

What is already known about this topic?

In 2015, the estimated HIV infection prevalence among persons who inject drugs (PWID) in 20 U.S. metropolitan statistical areas was $7 \%$.

What is added by this report?

In 2018, estimated HIV prevalence among PWID remained unchanged, and although overall syringe service program use did not significantly change, a substantial decrease in their use occurred among Black PWID.

What are the implications for public health practice?

Low-barrier access is needed to comprehensive and integrated needs-based syringe service programs (where legally permissible) that include provision of sterile syringes and safe syringe disposal, HIV and hepatitis C virus testing and referrals for treatment, HIV preexposure prophylaxis, and treatment for substance use and mental health disorders for PWID.

include provision of sterile syringes and safe syringe disposal, HIV and HCV testing and referrals to HIV and HCV treatment, HIV preexposure prophylaxis, and treatment for substance use and mental health disorders.

\section{Acknowledgments}

National HIV Behavioral Surveillance participants; CDC National HIV Behavioral Surveillance Team.

\section{National HIV Behavioral Surveillance Study Group}

Meaghan Abrego, Nassau-Suffolk, New York; Alia Al-Tayyib, Denver, Colorado; Bridget Anderson, Nassau-Suffolk, New York; Narquis Barak, New Orleans, Louisiana; Jeremy M. Beckford, New Orleans, Louisiana; Amisha Bhattari, Portland, Oregon; Kathleen A. Brady, Philadelphia, Pennsylvania; Meredith Brantley, Memphis, Tennessee; Sarah Braunstein, New York City, New York; Sidney Carrillo, New York City, New York; Onika Chambers, San Diego, California; Thomas Clyde, Chicago, Illinois; Sandra Miranda De León, San Juan, Puerto Rico; Jie Deng, Dallas, Texas; Rose Doherty, Boston, Massachusetts; Anna Flynn, San Diego, California; Colin Flynn, Baltimore, Maryland; David Forrest, Miami, Florida; Danielle German, Baltimore, Maryland; Sara Glick, Seattle, Washington; Vivian Griffin, Detroit, Michigan; Emily Higgins, Detroit, Michigan; Abdel R. Ibrahim, Newark, New Jersey; Tom Jaenicke, Seattle, Washington; Antonio D. Jimenez, Chicago, Illinois; Salma Khuwaja, Houston, Texas; Jennifer Kienzle, Virginia Beach, Virginia; Monina Klevens, Boston, Massachusetts; Jessica Lin, San Francisco, California; Zaida Lopez, Houston, Texas; Yingbo Ma, Los Angeles, California; Christopher Mathews, Memphis, Tennessee; Jack Marr, Memphis, Tennessee; María Pabón Martínez, San Juan, Puerto Rico; Willi McFarland, San Francisco, California; David Melton, Atlanta, Georgia; Timothy W. Menza, Portland, Oregon; Desmond Miller, San Francisco, California; Luis Moraga, Newark, New Jersey; Willie Nixon, Miami, Florida; Chrysanthus Nnumolu, Philadelphia, Pennsylvania; Conall O'Cleirigh, Boston, Massachusetts; Jenevieve Opoku, Washington, District of Columbia; E. Roberto Orellana, Portland, Oregon; Paige
Padgett, Houston, Texas; Jonathon Poe, Dallas, Texas; Marisa Ramos, San Diego, California; Toyah Reid, Virginia Beach, Virginia; Alexis Rivera, New York City, New York; William T. Robinson, New Orleans, Louisiana; Yadira Rolón-Colón, San Juan, Puerto Rico; Corrine Sanger, Detroit, Michigan; Hugo Santacruz, Los Angeles, California; Ekow Kwa Sey, Los Angeles, California; Jennifer Shinefeld, Philadelphia, Pennsylvania; Daniel Shodell, Denver, Colorado; Brandie Smith, Virginia Beach, Virginia; Emma Spencer, Miami, Florida; Ashley Tate, Nassau-Suffolk, New York; Jeff Todd, Atlanta, Georgia; Afework Wogayehu, Newark, New Jersey; Pascale Wortley, Atlanta, Georgia; Margaret Vaaler, Dallas, Texas.

Corresponding author: Senad Handanagic, ndv9@cdc.gov, 404-718-5659.

${ }^{1}$ Division of HIV Prevention, National Center for HIV, Viral Hepatitis, STD, and TB Prevention, CDC.

All authors have completed and submitted the International Committee of Medical Journal Editors form for disclosure of potential conflicts of interest. No potential conflicts of interest were disclosed.

\section{References}

1. CDC. HIV surveillance report: diagnoses of HIV infection in the United States and dependent areas, 2018 (updated). Atlanta, GA: US Department of Health and Human Services, CDC; 2020. https://www. cdc.gov/hiv/pdf/library/reports/surveillance/cdc-hiv-surveillance-report2018-updated-vol-31.pdf

2. CDC. HIV surveillance report: diagnoses of HIV infection among adults and adolescents in metropolitan statistical areas-United States and Puerto Rico, 2017. Atlanta, GA: US Department of Health and Human Services, CDC; 2019. https://www.cdc.gov/hiv/pdf/library/reports/ surveillance/cdc-hiv-surveillance-supplemental-report-vol-24-2.pdf

3. Burnett JC, Broz D, Spiller MW, Wejnert C, Paz-Bailey G. HIV Infection and HIV-associated behaviors among persons who inject drugs. MMWR Morb Mortal Wkly Rep 2018;67:23-8. PMID:29324726 https://doi. org/10.15585/mmwr.mm6701a5

4. Glick SN, Prohaska SM, LaKosky PA, Juarez AM, Corcorran MA, Des Jarlais DC. The impact of COVID-19 on syringe services programs in the United States. AIDS Behav 2020;24:2466-8. PMID:32333209 https://doi.org/10.1007/s10461-020-02886-2

5. Salganik MJ, Heckathorn DD. Sampling and estimation in hidden populations using respondent-driven sampling. Sociol Methodol 2004;34:193-240. https://doi.org/10.1111/j.0081-1750.2004.00152.x

6. Tempalski B, Pouget ER, Cleland CM, et al. Trends in the population prevalence of people who inject drugs in US metropolitan areas 1992 2007. PLoS One 2013;8:e64789. PMID:23755143 https://doi. org/10.1371/journal.pone.0064789

7. Branson BM, Handsfield HH, Lampe MA, et al. Revised recommendations for HIV testing of adults, adolescents, and pregnant women in healthcare settings. MMWR Recomm Rep 2006;55(RR-14). PMID:16988643 https://www.cdc.gov/mmwr/preview/mmwrhtml/rr5514a1.htm

8. Abdul-Quader AS, Feelemyer J, Modi S, et al. Effectiveness of structurallevel needle/syringe programs to reduce HCV and HIV infection among people who inject drugs: a systematic review. AIDS Behav 2013;17:2878-92. PMID:23975473 https://doi.org/10.1007/s10461-013-0593-y

9. Des Jarlais DC, Feelemyer J, LaKosky P, Szymanowski K, Arasteh K. Expansion of syringe service programs in the United States, 2015-2018. Am J Public Health 2020;110:517-9. PMID:32078343 https://doi. org/10.2105/AJPH.2019.305515

10. Lyss SB, Buchacz K, McClung R, Asher A, Oster AM. Responding to outbreaks of human immunodeficiency virus among persons who inject drugs-United States, 2016-2019: perspectives on recent experience and lessons learned. J Infect Dis 2020;222(Suppl 5):S239-49. PMID:32877545 https://doi.org/10.1093/infdis/jiaa1 12 